\title{
RECONNAISSANCE REPORT ON HIGHWAY DAMAGE FROM THE 18 JUNE 1994, ARTHURS PASS EARTHQUAKE
}

\author{
B.R. Paterson ${ }^{1}$ and P.J. Bourne-Webb ${ }^{2}$
}

\begin{abstract}
SUMMARY
The magnitude M 6.5 earthquake on 18 June 1994 centred about $20 \mathrm{~km}$ southwest of Arthurs Pass, caused considerable damage to State Highway 73 through Arthurs Pass National Park, closing the highway for several days and restricting traffic for more than a week. The most serious damage occurred in the Upper Otira Gorge where a large $\left(5-10,000 \mathrm{~m}^{3}\right)$ rock slide covered the road and partially dammed the Otira River. Other damage affecting the highway consisted of debris and rockfalls, and slumping along the edge of poorly compacted fills. Bridges and other structures were not damaged.
\end{abstract}

Damage to the highway appears to be associated with site specific factors rather than proximity to the epicentre. The pattern of ground damage may be due to the effects of topography on the propogation of earthquake waves, and variations in rock mass quality and destressing of valley slopes.

\section{INTRODUCTION}

State Highway 73 sustained considerable damage from the 18 June 1994, magnitude M 6.5 earthquake, resulting in closure of the highway through the Arthurs Pass National Park for several days, and restricting access for more than a week. The earthquake was centred about $20 \mathrm{~km}$ southwest of Arthurs Pass, and was followed a day later by a magnitude M 5.8 earthquake with an epicentre approximately $10 \mathrm{~km}$ further south near the head of Lake Coleridge (Figure 1). Numerous aftershocks were felt, including a magnitude M 5.6 on 21 June.

Damage to the highway was restricted to a $20 \mathrm{~km}$ length between Cass and Otira, the most serious damage occurring in the narrow Otira Gorge where a major rock slide occurred. In general, ground damage affecting SH 73 consisted of rock and soil falls from slopes above the highway, and slumping along the outer edge of embankment fills. There was no significant damage to bridges, and only minor damage to retaining structures was reported. Because of the threat of further slope instability above the highway, Gary Small, from Works Consultancy Services, and the authors were engaged by Transit New Zealand to determine the extent of landslide hazards, and what stabilisation measures would be required before the highway could be reopened.

The highway survey was conducted by recording the extent of damage at individual sites, and assessing the stability of batter

1 Consultant Engineering Geologist, Paterson \& Coates Associates, Christchurch.

2 Geotechnical Engineer, Works Consultancy Services, Wellington. slopes, using a hazard rating that distinguished between sections requiring urgent attention, prior to opening the highway, and those that could be delayed. A distinction was made between unstable material that would impact on the carriage way, and that which would not be a direct threat to road users. The survey was completed in two days.

\section{DESCRIPTION OF HIGHWAY DAMAGE}

\section{i) Cass - Arthurs Pass township}

Between Cass and the Waimakariri Bridge where the highway follows the southern side of the broad Waimakariri Valley, the effects of the earthquake were restricted to debris and rockfalls, which occurred mainly towards the eastern end where the highway sidles across steep, glaciated slopes of greywacke and greywacke-derived colluvium. Slope instability in this area is a function of the relaxed nature of the highly folded and fractured greywacke sandstone and siltstone, which strikes subparallel to the highway and dips steeply into the slope. Numerous blocks of rock up to about $1 \mathrm{~m}$ diameter were dislodged from the steep batters by earthquake shaking, and impacted on the highway. Release of the blocks, as well as the effects of earthquake shaking, loosened the rock mass to the degree that further rockfalls could be expected to occur at any time, but particularly during aftershocks and heavy rainfall (Figure 2). Because these blocks could impact directly on the highway, it was recommended that they be removed.

A large amount of rock debris fell onto the highway at Paddys Bend, a site with a history of rockfall caused by headward erosion of colluvium, and fretting of highly fragmented rock on a steep slope high above the highway. Slumping along the outer verge of the highway was minor throughout this section. 


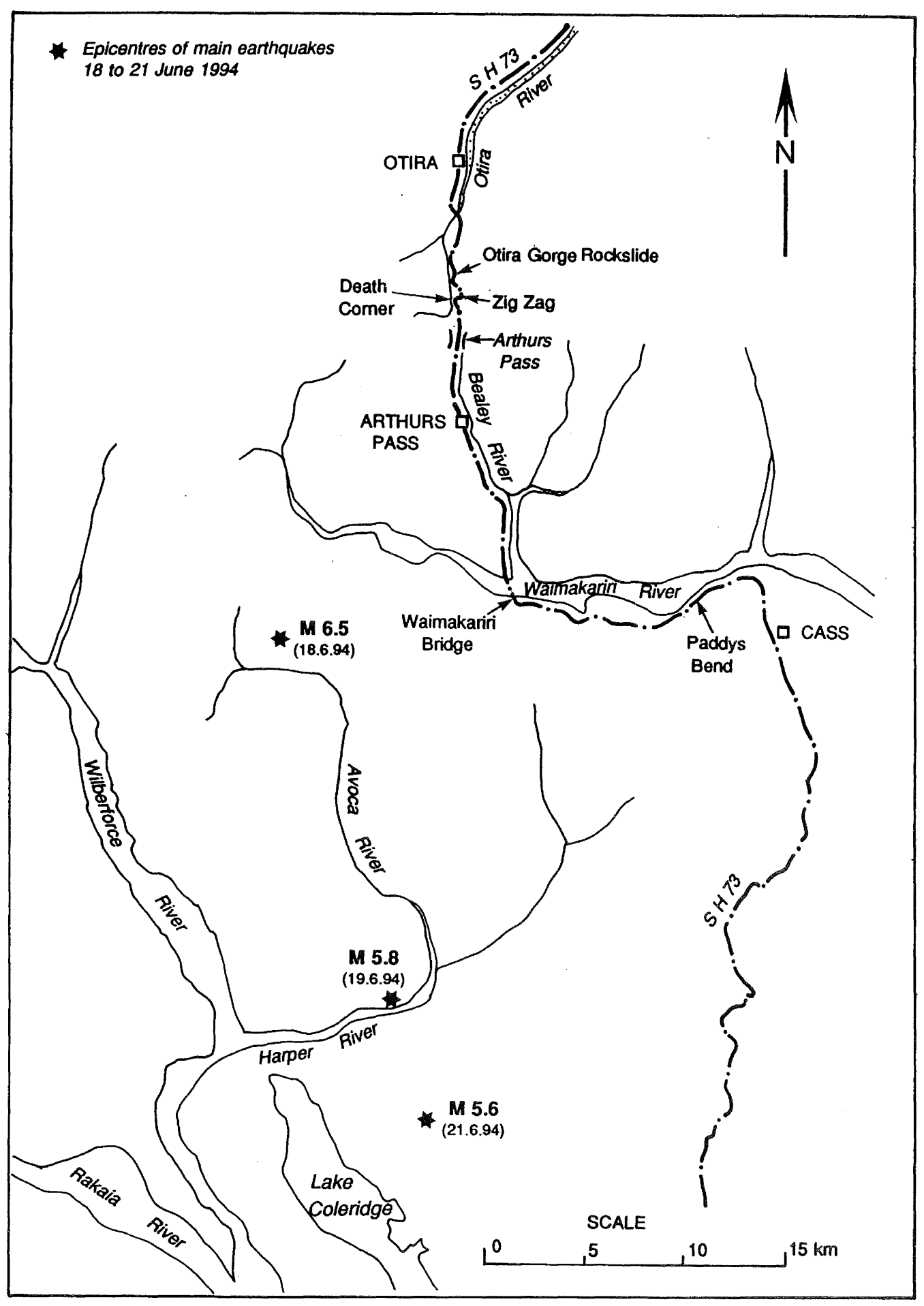

FIGURE 1 Map showing localities on State Highway 73 in relation to earthquake epicentres. 


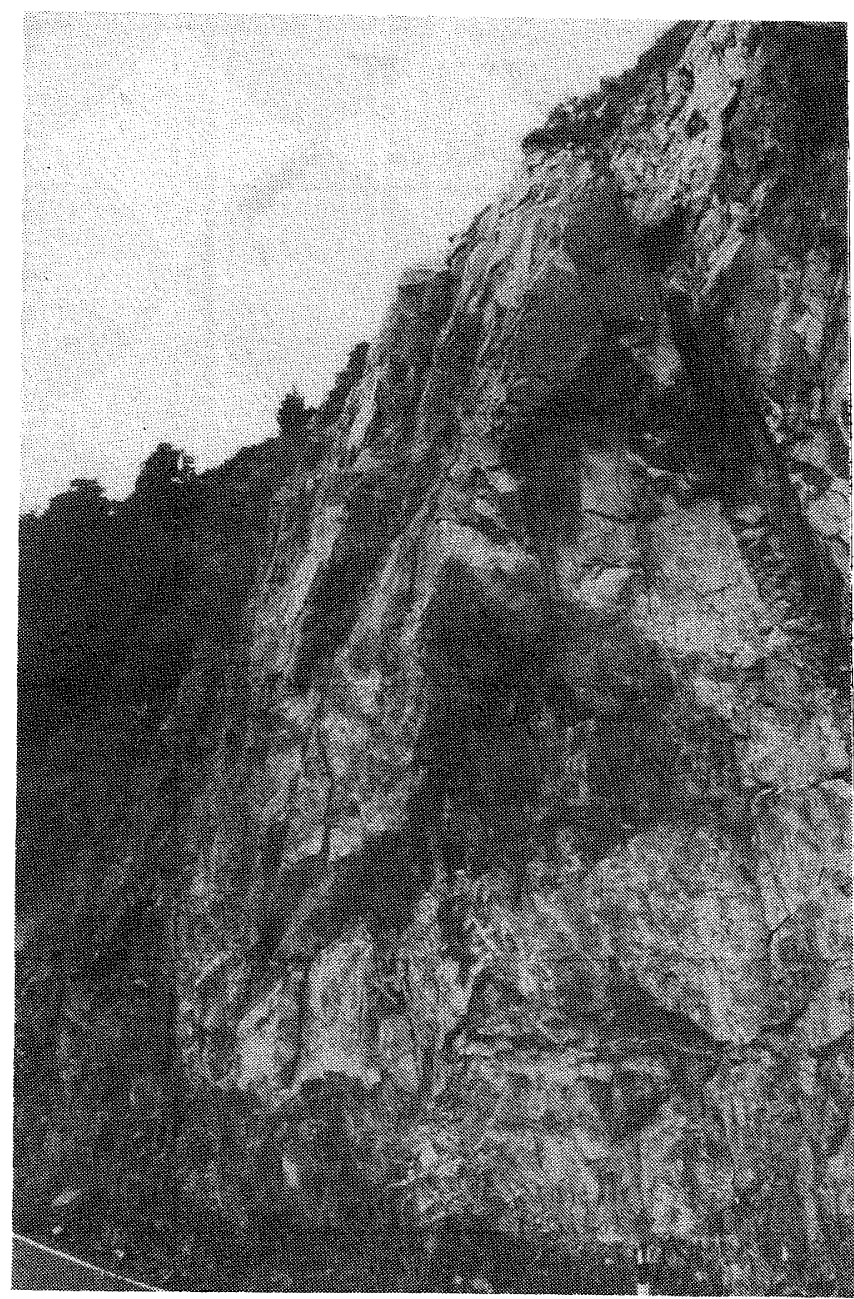

FIGURE 2 Destressed greywacke sandstone and argillite loosened by earthquake shaking . Locality on State Highway 73 near Paddy's Bend.

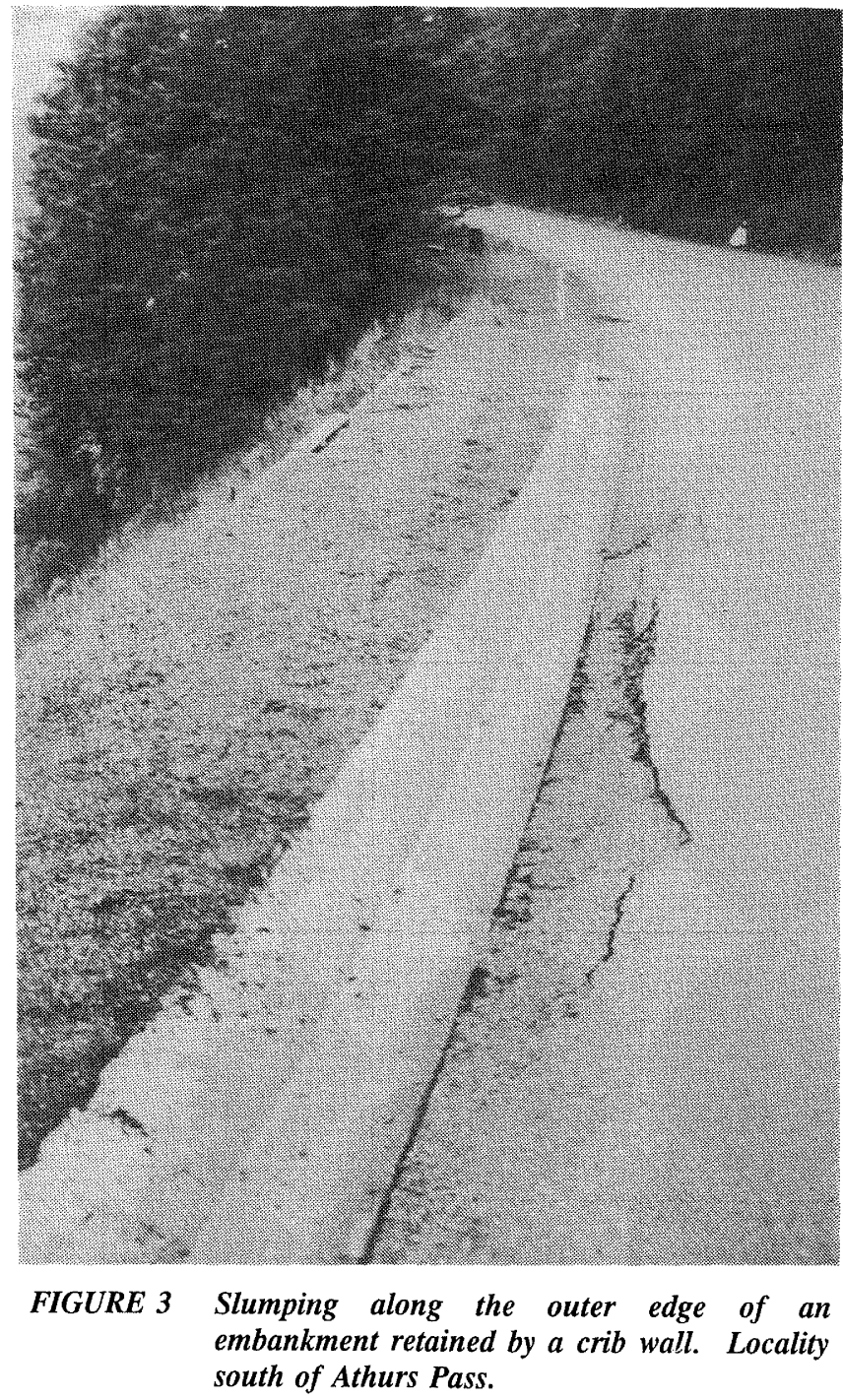

Slumping along the outer edge of the highway was very pronounced at several locations on the northern descent from the top of the Zig Zag, and near Death Corner at the southern end. At Death Corner the slumping occurred at the edge of an oversteepened, eroded slope, whereas at the northern end of the Zig Zag, slumping was restricted to poorly-compacted, side-cast fill There was no sign of ground damage across the summit of the Zig Zag where the slope below the highway is oversteepened by long-term progressive erosion, a location considered previously to be most at risk [2]. Numerous blocks of rock up to $1 \mathrm{~m}$ diameter fell onto the highway at the top of the Zig Zag from extensive screes immediately above the highway. No impact damage on the highway was observed, evidence that could indicate that large blocks had been dislodged from the upper ridge - the source of the rock avalanche deposit - and fallen into the Otira River, where the proposed viaduct is to be located.

\section{iii) Otira Gorge}

The largest slope failures that affected the highway were located in the Otira Gorge. A large rock slide on the eastern side of the valley, in the upper, narrow section of the gorge, partially dammed the Otira River (Figure 4). Several large debris slides/flows and numerous minor rockfalls occurred throughout the gorge (Figure 5), and the rock mass in numerous steep road cuts was loosened by earthquake shaking. Rock slopes at 


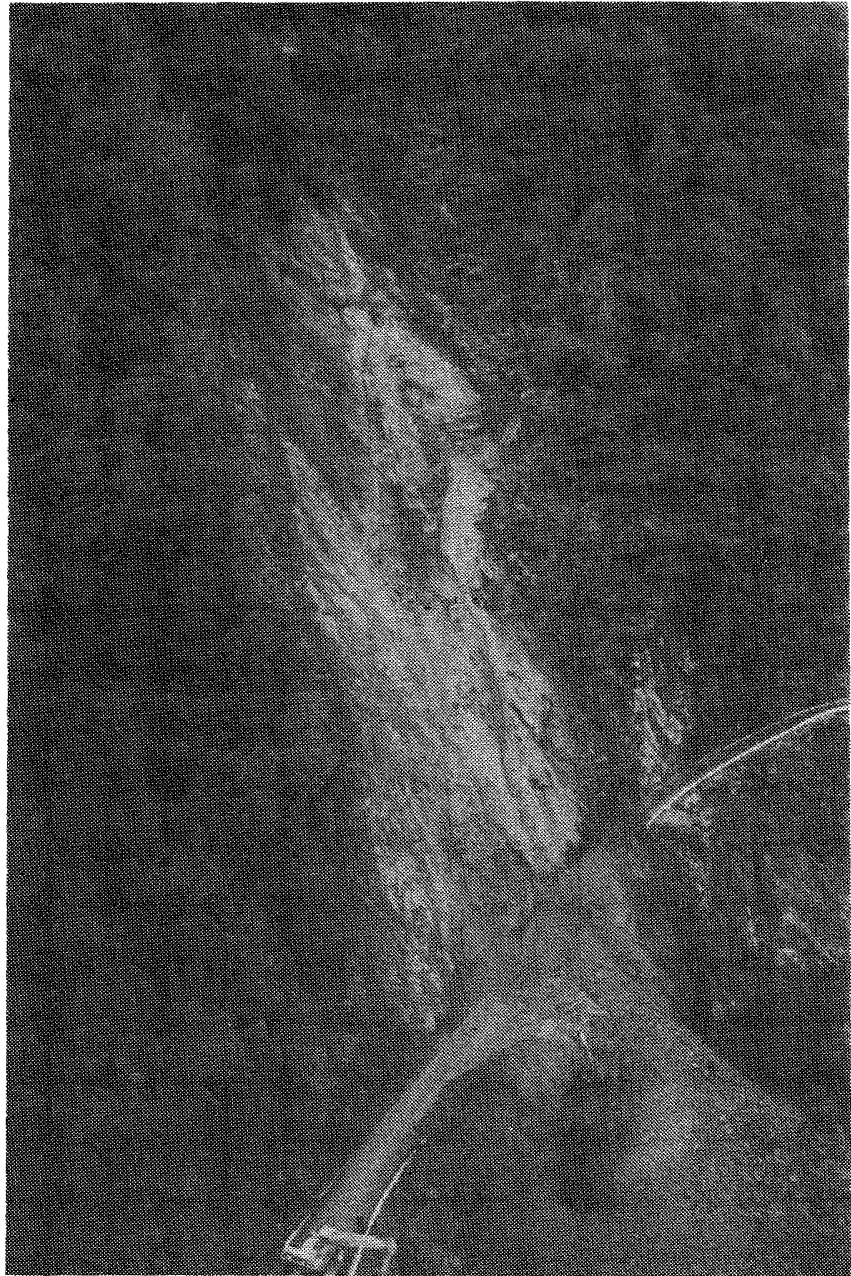

FIGURE 4 Rock slide above SH 73 partially damming the river in the upper Otira Gorge.

several bridge approaches were affected, causing concern about possible damage to the bridges.

The main rock slide is a classical wedge failure, delineated by undulating shear zones which form a shallow wedge, the intersection of which has a plunge (angle of declination) similar to the slope angle $\left(55^{\circ}\right)$. The failure surfaces are curved, daylighting at the top and bottom of the vertically-orientated wedge. This feature was identified previously as a potentially unstable wedge and was recommended for removal or stabilisation prior to upgrading of this section of highway [2]. The wedge failure extends to a height of $60-80 \mathrm{~m}$, and has a width of approximately $20 \mathrm{~m}$. The volume of slide debris is estimated to be $5-10,000 \mathrm{~m}^{3}$. Because of continuing risk of rockfall from material loosened by the slope failure, considerable effort was made to dislodge this material by sluicing it with water carried by two helicopters equipped with monsoon buckets.

\section{DISCUSSION}

The distribution and severity of highway damage and slope failures did not indicate whether the epicentre was located either east or west of the highway corridor. Also, the earthquake damage appeared to be associated with site specific factors rather than proximity to the epicentre.

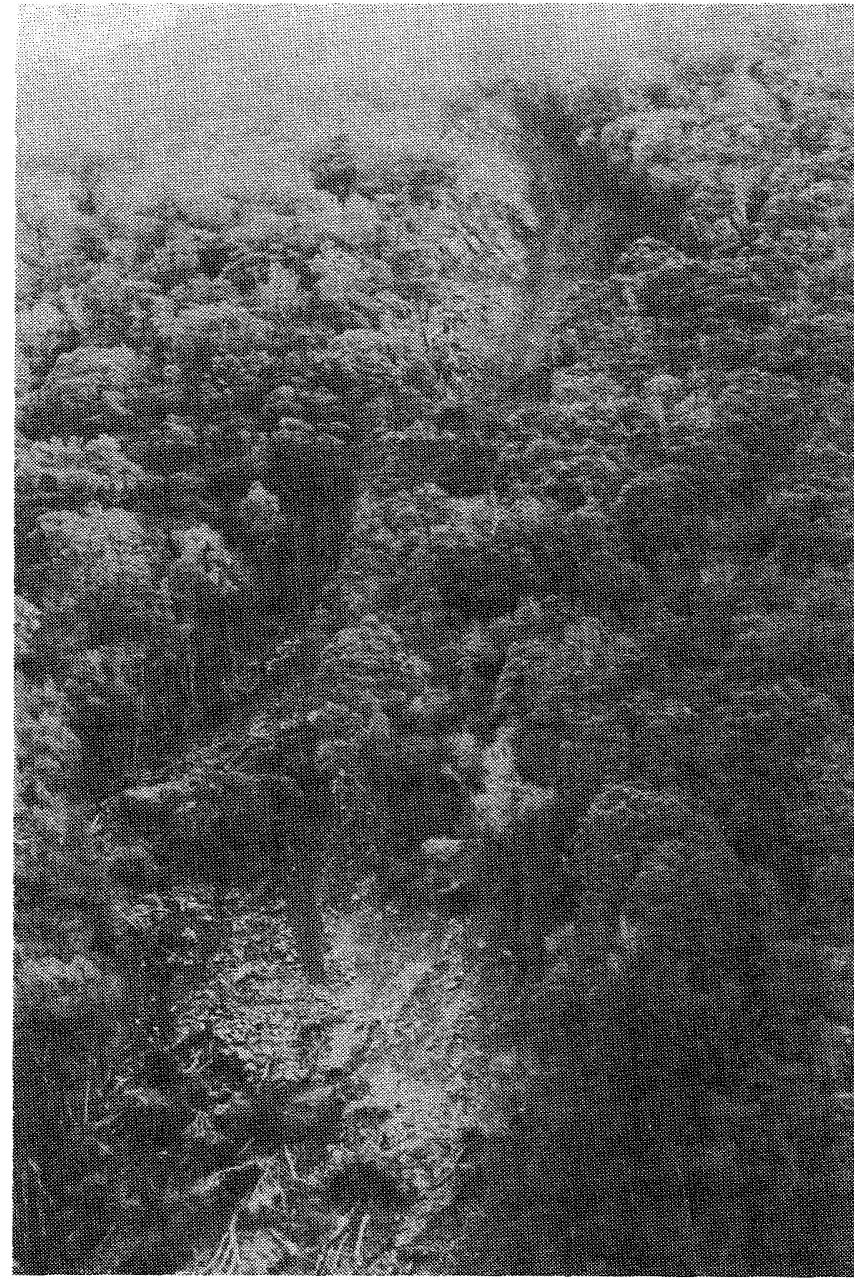

FIGURE 5 Debris slide on the western side of the Otira Gorge, opposite $\mathrm{SH} 73$.

The relatively minor landslide damage observed in the southern section between Cass and the Waimakariri Bridge could be largely due to the weak and highly fragmented nature of the materials intersected by the highway, and the steep slopes where the localised ground damage occurred. Also, the broad Waimakariri Valley has an east-west alignment, at right angles to the Bealey and Otira Valleys where the most serious damage occurred - such east-west slopes tended to be less affected by landsliding than those aligned in a north-south direction.

Features of the ground damage along the Bealey and Otira Valleys include:-

a) Sections of moderate ground damage were observed at either end of the highway corridor, separated by a central section of minor damage.

b) Moderate ground damage occurred in Otira Gorge, furthest from the instrumentally recorded epicentre.

c) There was only minimal ground damage, and relatively minor disturbance of the extensive scree deposits and destressed rock located above, and east of the top of the Zig Zag. 
This pattern of ground damage could be explained by the effects of topography on the propogation of earthquake waves, and variations in rock mass quality and destressing of valley slopes. For example, the narrow Otira Gorge which is aligned almost north-south, and is deeply-incised in the floor of a wide valley, may have had a funnelling effect on the propogation of earthquake waves, resulting in amplification. Conversely, the broad glaciated valleys may result in attenuation of the earthquake waves.

Ridges/slopes aligned normal to the direction of seismic wave propogation also may be shaken more strongly than those aligned parallel to the seismic waves. In addition, the rock mass in the steep-sided, youthfull, Otira Gorge is highly destressed and relaxed - a condition that leads to slope instability during rainstorms and earthquakes. By comparison, the mature slopes in the glacial valleys are less steep and the basement rock is either more competent, or is draped with superficial deposits.

\section{ACKNOWLEDGEMENTS}

The authors wish to thank Graham Hancox for useful comments and assistance. Permission from Transit New Zealand to publish this information from the highway survey is gratefully acknowledged. Earthquake magnitudes and locations of the epicentres were provided by the Institute of Geological \& Nuclear Sciences, Wellington.

\section{REFERENCES}

1 B R Paterson, M J McSaveney and M E Reyners, 1992, "The hazard of rock fall and rock avalanches at the Zig Zag, SH 73 Arthurs Pass", DSIR Geology \& Geophysics contract report 1992/14.

2 B R Paterson, 1987, "Engineering geology assessment of alternative highway options at the Zig Zag and Otira Gorge, Arthurs Pass", NZ Geological Survey report EG409. 